\title{
Impact of Entomopathogenic Fungi on the Growth, Development, and Health of Cabbage Growing under Water Stress
}

\author{
Surendra K. Dara ${ }^{*}$, Sumanth S. R. Dara ${ }^{2}$, Suchitra S. Dara ${ }^{2}$ \\ ${ }^{1}$ University of California Cooperative Extension, San Luis Obispo, Solutions, Bakersfield, California, USA \\ ${ }^{2}$ Global Agricultural Solutions, Bakersfield, California, USA \\ Email: *skdara@ucdavis.edu
}

How to cite this paper: Dara, S.K. Dara, S.S.R. and Dara, S.S. (2017) Impact of Entomopathogenic Fungi on the Growth, Development, and Health of Cabbage Growing under Water Stress. American Journal of Plant Sciences, 8, 1224-1233.

https://doi.org/10.4236/ajps.2017.86081

Received: March 17, 2017

Accepted: May 14, 2017

Published: May 17, 2017

Copyright $\odot 2017$ by authors and Scientific Research Publishing Inc. This work is licensed under the Creative Commons Attribution International License (CC BY 4.0).

http://creativecommons.org/licenses/by/4.0/

\section{Open Access}

\begin{abstract}
Entomopathogenic fungi such as Beauveria bassiana, Isaria fumosorosea, and Metarhizium brunneum are commonly used in the form of biopesticides to manage various arthropod pests. These fungi also form endophytic and mycorrhiza-like relationships with plants. This study aimed at evaluating the impact of three entomopathogenic fungi on the growth, development, and health of cabbage plants grown under artificial lighting with limited water. Beauveria bassiana had a positive influence on the survival, growth, health, length, and dry weight of cabbage. Other fungi also had a positive impact on some of the measured parameters. Other beneficial bacteria and mycorrhizae were also compared with the entomopathogenic fungi. This is the first report evaluating the non-entomopathogenic role of three entomopathogenic fungi on cabbage plants.
\end{abstract}

\section{Keywords}

Beauveria bassiana, Isaria fumosorosea, Metarhizium brunneum, Cabbage

\section{Introduction}

Entomopathogenic fungi Beauveria bassiana (Bals.-Criv.) Vuill. (Hypocreales: Cordycipitaceae), Isaria fumosorosea Wize (Hypocreales: Cordycipitaceae), and Metarhizium brunneum Petch (Hypocreales: Clavicipitaceae) are ubiquitous soilborne organisms that are pathogenic to various arthropod pests [1]-[8]. These fungi are commercially available for their primary use as biopesticides to control arthropod pests in various cropping systems. Recent studies show that entomopathogenic fungi form an endophytic relationship with banana [9], cotton [10], oilseed rape [11], sorghum [12], strawberry [13] and negatively impact 
herbivores. Other reports indicated that B. bassiana and Metarhizium anisopliae (Metch.) Sorokin had activity against plant pathogenic fungi and a virus [14] [15] [16]. Additionally, Metarhizium robertsii J.F. Bisch., Rehner \& Humber promoted root development [17] and nitrogen absorption [18] in switch grass and haricot beans and $M$. anisopliae mitigated salt stress in soybean [19] through endophytic interaction. These studies indicate a bigger role that entomopathogenic fungi could play in crop production in addition to their traditional role in crop protection. While some of the earlier studies used non-commercial isolates, species, or pure cultures of fungi, the current study was conducted using commercial formulations of B. bassiana, I. fumosorosea, and M. brunneum and comparing them with beneficial bacteria- and mycorrhizae-based products. The impact these materials have on the growth and health of cabbage under artificial lighting and reduced water conditions were evaluated.

\section{Materials and Methods}

Approximately 3-week old cabbage (variety Supreme Vantage) transplants, obtained from a commercial nursery (Plantel Nurseries Inc, Santa Maria, CA), were planted in Miracle-Gro Moisture Control Potting Mix (The Scotts Company, LLC, Marysville, OH) in $650 \mathrm{ml}$ plastic containers. This potting medium contained $0.21 \%$ nitrogen $(0.12 \%$ ammonical and $0.09 \%$ nitrate nitrogen), $0.07 \%$ available phosphate $\left(\mathrm{P}_{2} \mathrm{O}_{5}\right), 0.14 \%$ soluble potash $\left(\mathrm{K}_{2} \mathrm{O}\right)$, and $0.10 \%$ iron $(\mathrm{Fe})$. Each treatment had 10 plants and each plant was treated by pouring $100 \mathrm{ml}$ of respective treatment solution, prepared according to the field application rates, around the base of the plant. Water alone was added to control plants. Treatment solutions were made by adding the following materials to make up a final volume of $100 \mathrm{ml}: 1) 1 \mathrm{ml}$ of BotaniGard ES (LAM International Corp, Butte, MT)-active ingredient B. bassiana strain GHA, 2) $1 \mathrm{ml}$ of Met52 (Novozymes Biologicals, Inc, Salem, VA)-active ingredient $M$. brunneum ( $=M$. anisopliae) strain F52, 3) NoFly WP (Natural Industries, Inc, Spring, TX)-active ingredient Isaria fumosorosea (=Paecilomyces fumosoroseus) strain FE 9901, 4) $2.3 \mathrm{ml}$ of SumaGrow (SumaGrow USA, Westminster, CA)-active ingredients $12 \%$ humic acid and $1 \%$ of beneficial microbes that included Azorhizobium caulinodans, Bacillus subtilis, Pseudomonas fluorescens, Rhizobium phaseoli, and Trichoderma virens, 5) and $1 \mathrm{ml}$ of CropSignal (Advanced Soil Technologies, Bakersfield, CA)-active ingredient is a proprietary blend of minerals and micronutrients, 6) $0.03 \mathrm{ml}$ of Mykos Liquid (Reforestation Technologies International, Gilroy, CA)-active ingredient Rhizophagus irregularis, and 7) $\mathrm{H} 2 \mathrm{H}$ or Harvestto-Harvest (California Safe Soil, LLC, West Sacramento, CA) with 1\% water soluble nitrogen, $1 \%$ available phosphate, and an undefined blend of beneficial microbes. One plant from each treatment was placed in a tray and each tray represented a replication. Trays were arranged on a table and one $75 \mathrm{w}$ Philips Agro-Lite BR30 (Philips North America Corporation, Andover, MA) was placed in each corner of the table. Plants were grown in a dark room at a mean temperature of $22^{\circ} \mathrm{C}$ under 14:10 light: dark cycle and $50 \mathrm{ml}$ of water was added to each container on 42,50,64, and 81 days after planting. With artificial lighting and a 
limited amount of water, less than favorable field or greenhouse conditions were created to subject plants to stress and evaluate the impact of entomopathogenic fungi compared to other commercial products that are meant to promote plant growth, health, and yield (Table 1).

Various parameters were measured during the study. Plant stand was counted 40, 70, and 90 days after planting (DAP). Plant health was rated 40 and 70 DAP using a $0-5$ rating where $0=$ dead, $1=$ weak, $2=$ moderate-low, $3=$ moderate-high, $4=$ good, and $5=$ very good in terms of general health. Length of the roots and shoots was measured 90 DAP. Plants from each treatment were placed in a paper bag and dried for 8 days at $36.5^{\circ} \mathrm{C}$. After taking the dry weights, plants were sent to the University of California Davis analytical laboratory to measure nitrogen, phosphorous, potassium, and iron content. Samples were analyzed following standard analytical procedures using the combustion method (http://anlab.ucdavis.edu/using-the-lab/analysis/plant/522) for total nitrogen and the nitric acid digestion method

(http://anlab.ucdavis.edu/using-the-lab/analysis/plant/590) for the remaining nutrients. Since the plant material was insufficient due to small size of the plants, analysis was not conducted for individual plants, but for all plants within each treatment. Data were subjected to analysis of variance and significant means were separated using LSD test.

\section{Results}

Plant growth was stunted during the study period indicating less than favorable growth conditions as intended for this study. There were significant differences $(P \leq 0.001)$ among various treatments based on different measured parameters (Figure 1).

\subsection{Plant Stand}

Beauveria bassiana was the only treatment where all the plants survived for 90

Table 1. Average dry weight of the plant, nitrogen $(\mathrm{N})$, phosphorous $(\mathrm{P})$, potassium $(\mathrm{K})$, and iron $(\mathrm{Fe})$ content, and the ratio of plant weight and respective nutrients.

\begin{tabular}{|c|c|c|c|c|c|c|c|c|c|}
\hline Treatment & $\begin{array}{l}\text { Dry Weight } \\
(\mathrm{mg})\end{array}$ & $\begin{array}{c}\mathrm{N} \\
(\mathrm{mg})\end{array}$ & $\begin{array}{c}P \\
(\mathrm{mg})\end{array}$ & $\begin{array}{c}\mathrm{K} \\
(\mathrm{mg})\end{array}$ & $\begin{array}{c}\mathrm{Fe} \\
(\mathrm{mg})\end{array}$ & Weight/1 & Weight/P & Weight/K & Weight/Fe \\
\hline Miracle - Gro & 202.22 & 1.139 & 0.130 & 1.6100 & 0.0105 & 177.51 & 1558.44 & 125.61 & 19271.95 \\
\hline MG + BotaniGard & 234.00 & 0.889 & 0.136 & 1.6170 & 0.0097 & 263.16 & 1715.27 & 144.72 & 24213.08 \\
\hline MG + Met52 & 157.50 & 0.852 & 0.132 & 1.3330 & 0.0074 & 184.76 & 1197.60 & 118.17 & 21276.60 \\
\hline MG + NoFly & 92.22 & 0.509 & 0.074 & $0.748 \mathrm{C}$ & 0.0035 & 181.09 & 1246.54 & 123.29 & 26162.79 \\
\hline MG + SumaGrow & 55.00 & 1.312 & $\mathrm{~N} / \mathrm{A}^{*}$ & N/A & N/A & 41.93 & N/A & $\mathrm{N} / \mathrm{A}$ & N/A \\
\hline MG + CropSignal & 88.89 & 0.521 & 0.075 & 0.6670 & 0.0042 & 170.45 & 1178.01 & 133.33 & 21028.04 \\
\hline $\begin{array}{c}\text { MG + Mykos } \\
\text { Liquid }\end{array}$ & 90.00 & 0.532 & 0.072 & $0.778 \mathrm{C}$ & 0.0026 & 169.17 & 1253.48 & 115.68 & 35294.12 \\
\hline $\mathrm{MG}+\mathrm{H} 2 \mathrm{H}$ & 70.00 & 0.658 & 0.137 & 1.0710 & 0.0043 & 106.38 & 510.73 & 65.36 & 16129.03 \\
\hline
\end{tabular}

*Not available due to insufficient amount of dried plant material for analysis. 


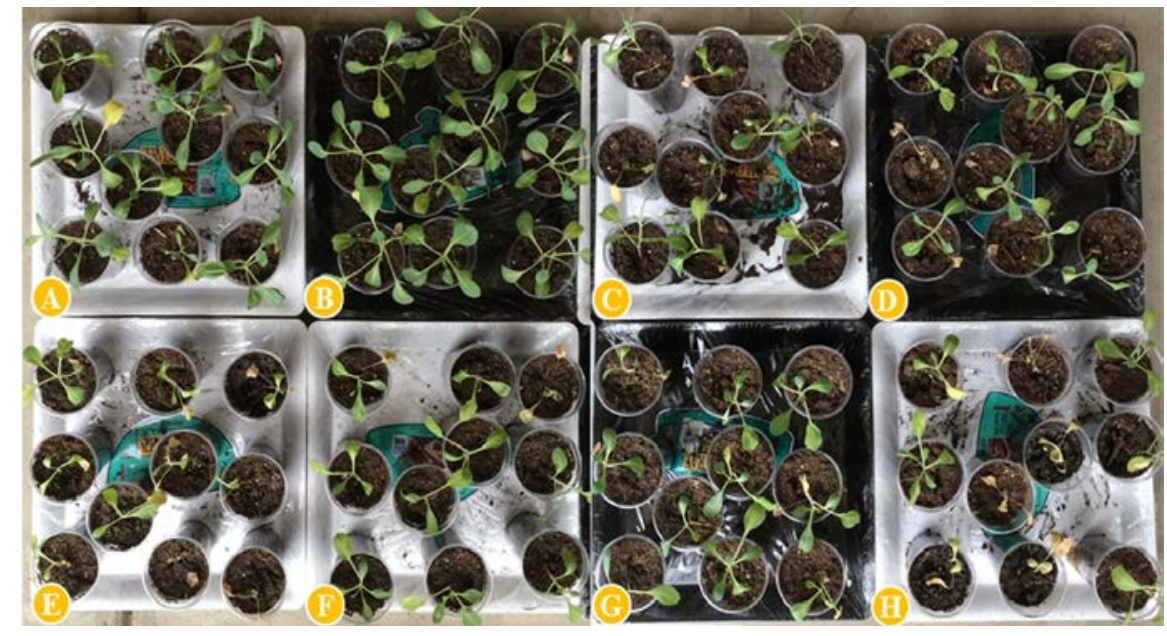

Figure 1. Condition of the surviving plants 90 days after planting (DAP) in different treatments [A. Miracle - Gro (MG), B. MG+B. bassiana, C. MG + M. brunneum, D. MG + I. fumosorosea, E. MG + SumaGrow, F. MG+CropSignal, G. MG + Mykos Liquid, and H. $\mathrm{MG}+\mathrm{H} 2 \mathrm{H}]$.

days of the observation period (Figure $2(\mathrm{a})$ ). There was a $10 \%$ to $80 \%$ reduction in the plantstand in other treatments during this period. Highest plant death was seen in SumaGrow and $\mathrm{H} 2 \mathrm{H}$ treatments $(P=0.001$ at $40 \mathrm{DAP}$ and $<0.00001$ at 70 and $90 \mathrm{DAP})$.

\subsection{Plant Health}

Plants treated with $B$. bassiana were significantly and uniformly healthier $(P<$ $0.00001)$ than the rest of the treatments on both observation dates with a 'very good' rating (Figure 2(b)). Health of the plants growing in Miracle-Gro with no supplemental materials also had a 'good' rating and was better than the health of plants in most of the remaining treatments. Plants treated with SumaGrow and $\mathrm{H} 2 \mathrm{H}$ had poor health with a 'weak' rating.

\subsection{Shoot and Root Length}

Length of the shoots was significantly higher $(P<0.00001)$ for plants treated with $B$. bassiana $(29 \mathrm{~cm})$ and $M$. brunneum $(27.6 \mathrm{~cm})$ compared to the rest of the treatments (Figure 2(c)). Plants treated with Miracle-Gro alone had a mean shoot length of $22.9 \mathrm{~cm}$, but the remaining treatments had significantly shorter shoots that varied from $13-18 \mathrm{~cm}$. Plants growing in Miracle-Gro alone and those supplemented with Crop Signal had significantly longer $(P<0.00001)$ roots.

\subsection{Shoot-to-Root Ratio}

Shoot-to-root ratio, which indicates the shoot growth in relation to the root growth, was significantly higher $(P<0.00001)$ for plants that were treated with B. bassiana and $M$. brunneum (Figure 2(d)) followed by those treated with $I$. fumosorosea and others. 


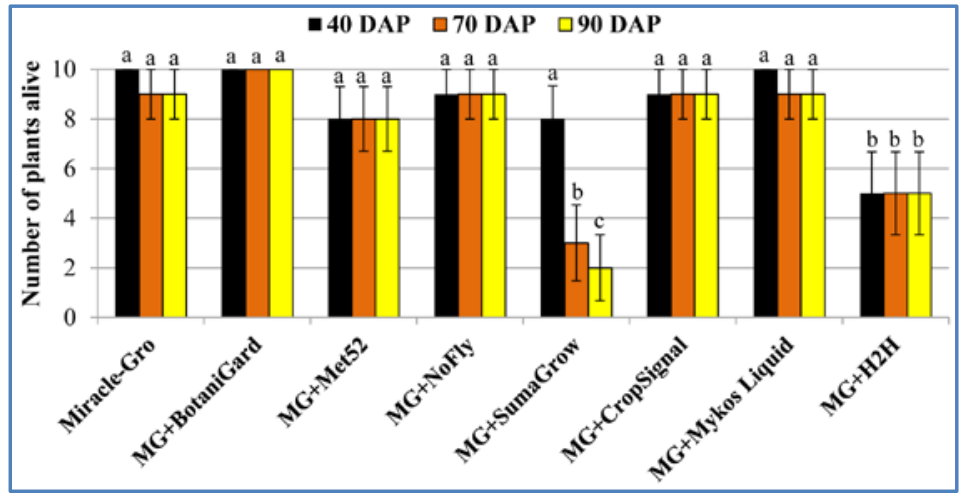

(a)

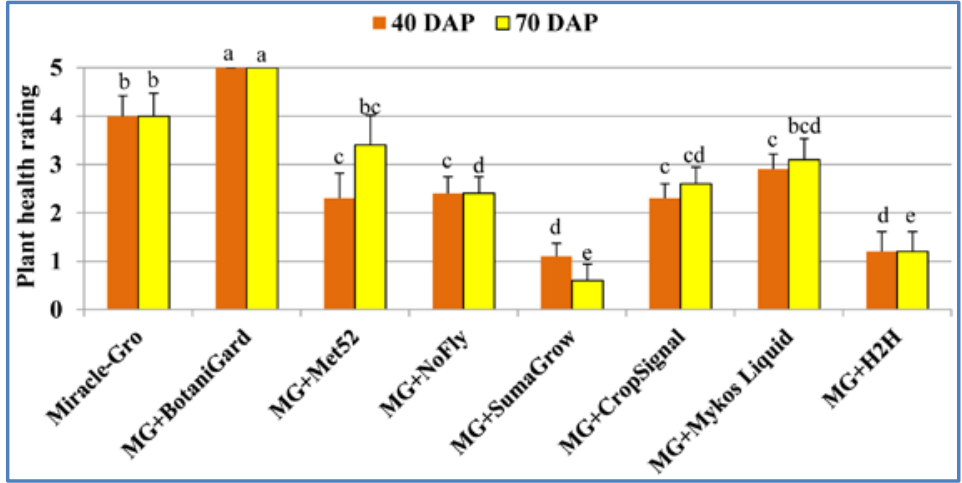

(b)

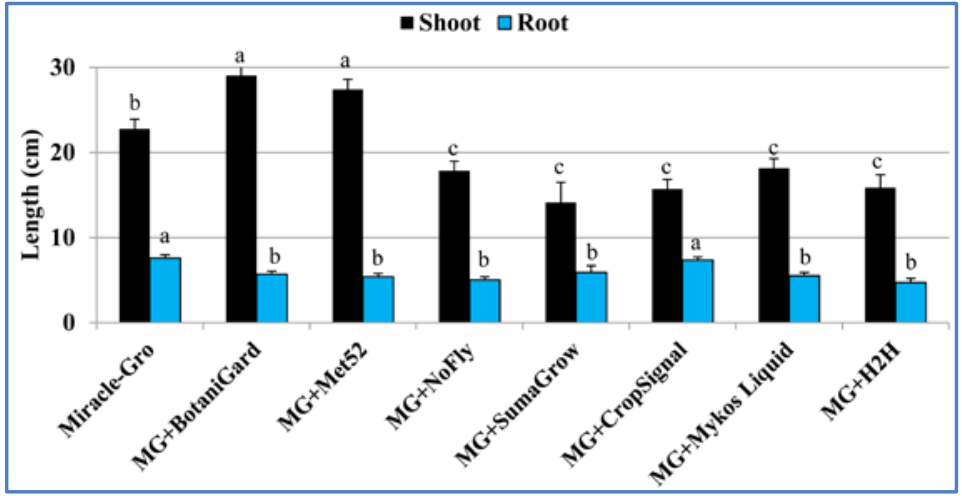

(c)

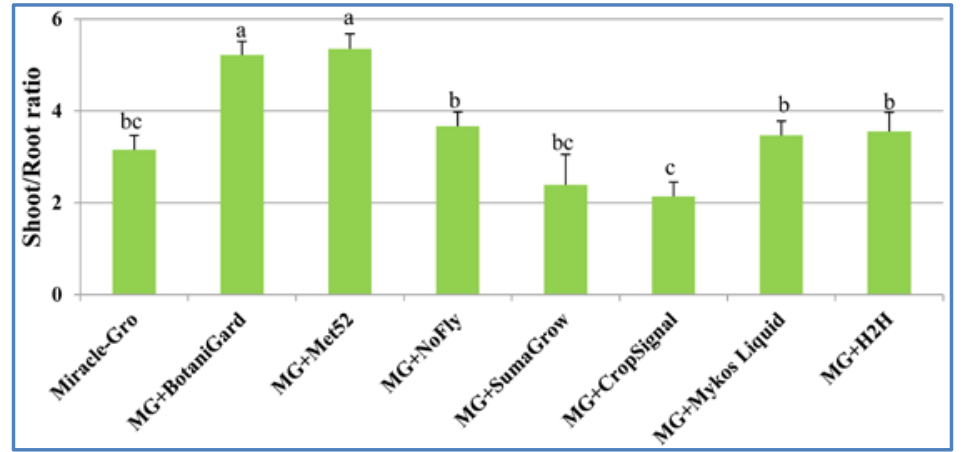

(d)

Figure 2. Plant stand (a); plant health (b); shoot and root length (c); and shoot-to-root ratio (d) in different treatments at 40,70 , or 90 days after planting (DAP). 


\subsection{Nutrient Content}

Since all the surviving plants, $90 \mathrm{DAP}$, were combined for the dry weight or analyzed for the nutrient content as a single sample for each treatment, data were not sufficient for statistical analysis. Plants treated with B. bassiana had relatively higher biomass. When the plant weight, as a result of accumulated nutrients, was calculated by dividing the weight with respective nutrient content, $B$. bassiana appeared to have relatively higher output for nitrogen, phosphorus, and potassium based on numerical values. Such an effect for iron was seen in all treatments compared to Miracle-Gro alone. However, these values are only indicative as they were not subjected to statistical analysis.

\section{Discussion}

Although both SumaGrow and $\mathrm{H} 2 \mathrm{H}$ contained beneficial microbes, plants treated with these materials did not survive well and were not able to maintain good health. Mycorrhizal products are typically not used in cole crops as crucifers are thought to have poor or no mycorrhizal relationship. Both SumaGrow and Mykos Liquid, which contained mycorrhizae, served as positive controls in this study. In general, B. bassiana had a significant positive impact on the survival, health, and growth of the plants compared to the remaining treatments while $M$. brunneum had a similar positive effect on the shoot length and shootto-root ratio.

The positive impact of entomopathogenic fungi on plants is generally attributed to the pest control they provide. A recent review [20] discussed multiple roles of entomopathogenic fungi as endophytes and plant disease antagonists, but contemplated on rhizosphere colonization and possible plant growth promotion as there was no published evidence of the direct impact of entomopathogenic fungi on plant growth at the time of the review. However, a recent study showed the positive impact of $B$. bassiana on strawberry plant growth regardless of the pest damage [21]. In a different study, strawberry plants treated with $M$. brunneum withstood infestations by two spotted spider mite, Tetranychus urticae Koch better than untreated plants [22]. Although the mode of action was not clear, $M$. brunneum could have promoted the root growth in this study similar to M. roberts ii in switch grass and haricot beans [17]. Spider mites generally thrive on water stressed plants [23] and M. brunneum could have improved the water absorption and helped strawberry plants withstand spider mite pressure.

Insects cause a significant loss to plant nutrients through their feeding damage, but plants also seem to have developed a mechanism to recover those nutrients, especially nitrogen, from insects through entomopathogenic fungi that have endophytic interactions with plants. As a result, whether or not insects are present in the soil, plants have an advantage to form an endophytic or mycorrhiza-like relationship with soilborne entomopathogens. It also appears that $B$. bassiana and Metarhizium spp. transfer insect-derived nitrogen to plants as seen in a study with monocots and dicots [24]. The current study was conducted in 
the absence of pest insects and both $B$. bassiana and $M$. brunneum promoted plant growth demonstrating their role as nutrient and moisture absorption channels for plants. Mycorrhizae are known to improve plant growth, yield, water or nutrient absorption in citrus [25], corn [26], pepper [27], olive [28], onion [29], and snapdragon [30] and their role is especially important for plants growing in poor soils or under drought or saline conditions. Mycorrhizae also helped the seedlings of a tropical tree, Diconyina guianensis to grow well under poor light conditions [31]. Crucifers are previously thought to be non-mycorrhizal [32], but later studies reported varying degrees of mycorrhizal relationships in crucifers sometimes dependent on glucosinolate content [33] [34] [35] [36]. However, mycorrhizae-based products are generally not used in cole crop production. As the current study indicated that B. bassiana and M. brunneum helped cabbage plants to survive well, grow better, and maintain good health under low water and light conditions, these fungi may play a role in cabbage and other cole crop production.

\section{Conclusion}

This is the first report of the direct impact of entomopathogenic fungi on cabbage plant growing under stressful conditions. The positive effect of $B$. bassiana, and to some extent $M$. brunneum, is important to expand their role in practical agriculture beyond pest management. If they are used to promote plant growth, improve water and nutrient absorption, withstand saline or drought conditions, and increase yields in addition to their typical use as biopesticides, then they can play a critical role as holistic tools in sustainable agriculture. The higher cost of biopesticides, compared to chemical pesticides, is a limitation for their extensive use. If products based on entomopathogenic fungi have multiple roles in both crop production and protection, their cost effectiveness improves and opens up new avenues for their increased use.

\section{Acknowledgements}

Thanks to Plantel Nurseries, Inc. for donating cabbage transplants and Advanced Soil Technologies, BioWorks Inc, California Safe Soil, Novozymes Biologicals, Reforestation Technologies International, and SumaGrow USA for various treatment materials used in this study.

\section{References}

[1] Behle, R.W., Jackson, M.A. and Flor-Weiler, L.B. (2013) Efficacy of a Granular Formulation Containing Metarhizium brunneum F52 (Hypocreales: Clavicipitaceae) Microsclerotia against Nymphs of Ixodes scapularis (Acari: Ixoididae). Journal of Economic Entomology, 106, 57-63. https://doi.org/10.1603/EC12226

[2] Bidochka, M.J., Kasperski, J.E. and Wild, G.A.M. (1998) Occurrence of the Entomopathogenic Fungi Metarhizium anisopliae and Beauveria bassiana in Soils from Temperate and Near-Northern Habitats. Canadian Journal of Botany, 76, 1198 1204. https://doi.org/10.1139/b98-115

[3] Cantone, F. and Vandenberg, J. (1998) Intraspecific Diversity in Paecilomyces fu- 
mosoroseus. Mycological Research, 102, 209-215.

[4] Gouli, V., Gouli, S., Skinner, M., Hamilton, G., Kim, J.S. and Parker, B.L. (2012) Virulence of Select Entomopathogenic Fungi to the Brown Marmorated Stink Bug, Halyomorpha halys (Stål) (Heteroptera: Pentatomidae). Pest Management Science, 68, 155-157. https://doi.org/10.1002/ps.2310

[5] Padulla, L.F.L. and Alves, S.B. (2009) Suscetibilidade de ninfas de Diaphorina citri a fungos entomopatogênicos. Arquivos do Instituto Biológico, 76, 297-302.

[6] Reddy, G.V.P., Zhao, Z. and Humber, R.A. (2014) Laboratory and Field Efficacy of Entomopathogenic Fungi for the Management of the Sweet Potato Weevil, Cylas formicarius (Coleoptera: Brentidae). Journal of Invertebrate Pathology, 122, 10-15.

[7] Roberts, D.W. and St. Leger, R.J. (2004) Metarhizium spp., Cosmopolitan InsectPathogenic Fungi: Mycological Aspects. Advances in Applied Microbiology, 54, 170 .

[8] Zimmerman, G. (2008) The Entomopathogenic Fungi Isaria farinosa (Formerly Paecilomyces farinosa) and the Isaria fumosorosea Species Complex (Formerly Paecilomyces fumosoroseus): Biology, Ecology, and Use in Biological Control. Biocontrol Science and Technology, 18, 865-901. https://doi.org/10.1080/09583150802471812

[9] Akello, J., Dubois, T., Coyne, D. and Kyamanywa, S. (2008) Endophytic Beauveria bassiana in Banana (Musa spp.) Reduces Banana Weevil (Cosmopolites sordidus) Fitness and Damage. Crop Protection, 27, 437-1441.

[10] Lopez, D.C., Zhu-Salzman, K., Ek-Ramos, M.J. and Sword, G.A. (2014) The Entomopathogenic Fungal Endophytes Purpureocillium lilacinum (Formerly Paecilomyces lilacinus) and Beauveria bassiana Negatively Affected Cotton Aphid Reproduction under Both Greenhouse and Field Conditions. PLoS ONE, 9, e103891. https://doi.org/10.1371/journal.pone.0103891

[11] Batta, Y.A. (2013) Efficacy of Endophytic and Applied Metarhizium anisopliae (Metch.) Sorokin (Ascomycota: Hypocreales) against Larvae of Plutella xylostella L. (Yponomeutidae: Lepidoptera) Infesting Brassica napus Plants. Crop Protection, 44, 128-134.

[12] Tefera, T. and Vidal, S. (2009) Effect of Inoculation Method and Plant Growth Medium on Endophytic Colonization of Sorghum by the Entomopathogenic Fungus Beauveria bassiana. BioControl, 54, 663-669. https://doi.org/10.1007/s10526-009-9216-y

[13] Dara, S.K., Dara, S.R. and Dara, S.S. (2013) Endophytic Colonization and Pest Management Potential of Beauveria bassiana in Strawberries. Journal of Berry Research, 3, 203-211.

[14] Bisutti, I.L., Steen, C. and Stephan, D. (2013) Does Metarhizium anisopliae Influence Strawberries in Presence of Pest and Disease? 46th Annual Meeting of the Society for Invertebrate Pathology and Microbial Control, Pittsburgh, PA, 11-15 August 2013, 88 .

[15] Jaber, L.R. and Salem, N.M. (2014) Endophytic Colonisation of Squash by the Fungal Entomopathogen Beauveria bassiana (Ascomycota: Hypocreales) for Managing Zucchini yellow mosaic virus in Cucurbits. Biocontrol Science and Technology, 24, 1096-1109. https://doi.org/10.1080/09583157.2014.923379

[16] Ownley, B.H., Pereira, R.M., Klingeman, W.E., Quigley, N.B. and Leckie, B.M. (2004) Beauveria bassiana, a Dual Purpose Biocontrol Organism, with Activity against Insect Pests and Plant Pathogens. In: Lartey, R.T. and Cesar, A.J., Eds., Emerging Concepts in Plant Health Management, Research Signpost, India, 255269. 
[17] Sasan, R.K. and Bidochka, M.J. (2012) The Insect-Pathogenic Fungus Metarhizium robertsii (Clavicipitaceae) Is Also an Endophyte That Stimulates Plant Root Development. American Journal of Botany, 99, 101-107. https://doi.org/10.3732/ajb.1100136

[18] Behie, S.W., Zelisko, P.M. and Bidochka, M.J. (2012) Endophytic Insect-Parasitic Fungi Translocate Nitrogen Directly from Insects to Plants. Science, 336, 15761577. https://doi.org/10.1126/science.1222289

[19] Khan, A.L., Hamayun, M., Khan, S.A., Kang, S.M., Shinwari, Z.K., Kamran, M., Ur Rehman, S., Kim, J.G. and Lee, I.J. (2012) Pure Culture of Metarhizium anisopliae LHL07 Reprograms Soybean to Higher Growth and Mitigates Salt Stress. World Journal of Microbiology and Biotechnology, 28, 1483-1494. https://doi.org/10.1007/s11274-011-0950-9

[20] Vega, F.E., Goettel, M.S., Blackwell, M., Chandler, D., Jackson, M.A., Keller, S., Koike, M., Maniania, N.K., Monzon, A., Ownley, B.H., Pell, J.K., Rangel, D.E.N. and Roy, H.E. (2009) Fungal Entomopathogens: New Insights on Their Ecology. Fungal Ecology, 2, 149-159.

[21] Dara, S.K. (2014) Beauveria bassiana and California Strawberries: Endophytic, Mycorrhizal, and Entomopathogenic Interactions. 46th Annual Meeting of the Society for Invertebrate Pathology and Microbial Control, Pittsburgh, PA, 11-15 August 2013, 148.

[22] Dara, S.K. and Dara, S.R. (2015) Soil Application of the Entomopathogenic Fungus Metarhizium brunneum Protects Strawberry Plants from Spider Mite Damage. UCANR eNewsletter Strawberries and Vegetables, 18 February 2015. http://ucanr.edu/blogs/blogcore/postdetail.cfm?postnum $=16821$

[23] Stavrinides, M.C., Daane, K.M., Lampinen, B.D. and Mills, N.J. (2010) Plant Water Stress, Leaf Temperature, and Spider Mite (Acari: Tetranychidae) Outbreaks in California Vineyards. Environmental Entomology, 39, 1232-1241.

https://doi.org/10.1603/EN09288

[24] Behie, S.W. and Bidochka, M.J. (2014) Nutrient Transfer in Plant-Fungal Symbioses. Trends in Plant Science, 19, 734-740. https://doi.org/10.1016/j.tplants.2014.06.007

[25] Wu, Q.S. and Zou, Y. (2009) Mycorrhizal Influence on Nutrient Uptake of Citrus Exposed to Drought Stress. Philippine Agricultural Scientist, 92, 33-38.

[26] Amerian, M.R. and Stewart, W.S. (2001) Effect of Two Species of Arbuscular Mycorrhizal Fungi on Growth, Assimilation and Leaf Water Relations in Maize (Zea mays). Aspects of Applied Biology, 63, 1-6.

[27] Nedorost, L., Vojtiskova, J. and Pokluda, R. (2014) Influence of Watering Regime and Mycorrhizal Inoculation on Growth and Nutrient Uptake of Pepper (Capsicum annuum L.). Acta Horticulturae, 1038, 559-564.

https://doi.org/10.17660/ActaHortic.2014.1038.70

[28] Porras-Soriano, A., Soriano-Martin, M.L., Porras-Piedra, A. and Azcon, R. (2009) Arbuscular Mycorrhizal Fungi Increased Growth, Nutrient Uptake and Tolerance to Salinity in Olive Trees under Nursery Conditions. Journal of Plant Physiology, 166, 1350-1359.

[29] Bolandnazar, S., Aliasgarzad, N., Neishabury, M.R. and Chaparzadeh, N. (2007) Mycorrhizal Colonization Improves Onion (Allium cepa L.) Yield and Water Use Efficiency under Water Deficit Condition. Scientia Horticulturae 114, 11-15.

[30] Asrar, A.A., Abdel-Fattah, G.M. and Elhindi, K.M. (2012) Improving Growth, Flower Yield, and Water Relations of Snapdragon (Antirhinum majus L.) Plants Grown under Well-Watered and Water-Stress Conditions Using Arbuscular My- 
corrhizal Fungi. Photosynthetica, 50, 305-316.

https://doi.org/10.1007/s11099-012-0024-8

[31] Bereau, M., Bonal, D., Louisanna, E. and Garbaye, J. (2005) Do Mycorrhizas Improve Tropical Tree Seedling Performance under Water Stress and Low Light Conditions? A Case Study with Dicorynia guianensis (Caesalpiniaceae). Journal of Tropical Ecology, 21, 375-381. https://doi.org/10.1017/S0266467405002348

[32] Gerdemann, J.W. (1968) Vesicular-Arbuscular Mycorrhizae and Plant Growth. Annual Review of Phytopathology, 6, 397-418. https://doi.org/10.1146/annurev.py.06.090168.002145

[33] Medve, R.J. (1983) The Mycorrhizal Status of the Cruciferae. The American Midland Naturalist, 109, 406-408. https://doi.org/10.2307/2425422

[34] Glenn, M.G., Chew, F.S. and Williams, P.H. (1988) Influence of Glucosinolate Content of Brassica (Cruciferae) Roots on Growth of Vesicular-Arbuscular Mycorrhizal Fungi. New Phytologist, 110, 217-225. https://doi.org/10.1111/j.1469-8137.1988.tb00255.x

[35] DeMars, B.G. and Boerner, R.E.J. (1995) Arbuscular Mycorrhizal Development in Three Crucifers. Mycorrhiza, 5, 405-408. https://doi.org/10.1007/BF00213440

[36] Vierheilig, H., Bennett, R., Kiddle, G., Kaldorf, M. and Ludwig-Muller, J. (2000) Differences in Glucosinolate Patterns and Arbuscular Mycorrhizal Status of Glucosinolate-Containing Plant Species. New Phytologist, 146, 343-352.

https://doi.org/10.1046/j.1469-8137.2000.00642.x

Scientific Research Publishing

Submit or recommend next manuscript to SCIRP and we will provide best service for you:

Accepting pre-submission inquiries through Email, Facebook, LinkedIn, Twitter, etc. A wide selection of journals (inclusive of 9 subjects, more than 200 journals)

Providing 24-hour high-quality service

User-friendly online submission system

Fair and swift peer-review system

Efficient typesetting and proofreading procedure

Display of the result of downloads and visits, as well as the number of cited articles

Maximum dissemination of your research work

Submit your manuscript at: http://papersubmission.scirp.org/

Or contact ajps@scirp.org 